\title{
Radiolabeled Humanized Anti-CD3 Monoclonal Antibody Visilizumab for Imaging Human T-Lymphocytes
}

Gaurav Malviya ${ }^{1}$, Calogero D’Alessandria ${ }^{2}$, Elena Bonanno ${ }^{3}$, Vladimir Vexler ${ }^{4}$, Roberto Massari ${ }^{5}$, Carlo Trotta ${ }^{5}$, Francesco Scopinaro ${ }^{2}$, Rudi Dierckx ${ }^{1}$, and Alberto Signore ${ }^{1,2}$

${ }^{1}$ Department of Nuclear Medicine and Molecular Imaging, University Medical Centre Groningen, University of Groningen, Groningen, The Netherlands; ${ }^{2}$ Nuclear Medicine Unit, II Faculty of Medicine and Surgery, Sapienza University of Rome, Rome, Italy; ${ }^{3}$ Department of Biopathology and Diagnostic Imaging, University Tor Vergata, Rome, Italy; ${ }^{4}$ PDL BioPharma, Inc., Redwood City, California; and Institute of Biomedical Engineering (IsIB)—National Council of Research, Rome, Italy

Visilizumab is an $\lg _{2}$ humanized monoclonal antibody (mAb) characterized by non-Fc $\gamma R$ binding and specific to the CD3 antigen, expressed on more than $95 \%$ of circulating resting T-lymphocytes and on activated T-lymphocytes homing in inflamed tissues. We hypothesized that the use of a radiolabeled anti-CD3 antibody might serve as a diagnostic tool for imaging T-cell traffic and lymphocytic infiltration of tissues and organs affected by autoimmune diseases. Here we describe the results of in vitro and animal experiments with $99 \mathrm{mTc}$-succinimidyl6-hydrazinonicotinate hydrochloride (SHNH)-visilizumab. Methods: For mAb labeling, we used a 2-step method with a heterobifunctional linker SHNH. Several titrations were performed to obtain the best labeling efficiency. In vitro quality controls included stability assay, cysteine challenge, sodium dodecyl sulfate polyacrylamide gel electrophoresis, binding assay, and immunoreactivity assay. In vivo studies by high-resolution images were performed at 6 and $24 \mathrm{~h}$ after the injection of ${ }^{99 \mathrm{~m} T \mathrm{~T}-}$ $\mathrm{SHNH}-$ visilizumab. These included cell-targeting experiments in BALB/c mice xenografted subcutaneously with an increasing number of HuT78 cells in the leg and displaced with an excess of cold antibody. We also studied irradiated severe combined immunodeficient (SCID) mice reconstituted with human peripheral blood mononuclear cells (hPBMCs) and injected with ${ }^{99 m}$ Tclabeled visilizumab or control $\mathrm{mAb}$. After dynamic imaging for $3 \mathrm{~h}$, major organs were removed, counted, and processed for immunohistologic examination. Results: Visilizumab was labeled with HYNIC with high labeling efficiency (>90\%) and high specific activity (SA; 10,360-11,100 MBq/mg), with retained biochemical integrity and in vitro binding activity to CD3-positive cells. The in vivo targeting experiment showed a proportional increase of specific uptake with the number of injected cells, both at 6 and at $24 \mathrm{~h}$, and the in vivo competition study demonstrated more than $60 \%$ decreased uptake after an excess of unlabeled antibody. In SCID mice, hPBMCs in different tissues were detected by ${ }^{99 m}$ Tc-labeled visilizumab and confirmed by histology. Conclusion: Visilizumab can be efficiently labeled with $99 \mathrm{mTc}$ with high efficiency and SA and could be a valuable tool

Received Oct. 21, 2008; revision accepted Jun. 30, 2009.

For correspondence or reprints contact: Alberto Signore, Nuclear Medicine Department, Sapienza University of Rome, St. Andrea

Hospital, Via di Grottarossa 1035, 00189 Rome, Italy.

E-mail: alberto.signore@uniroma1.it

COPYRIGHT $\odot 2009$ by the Society of Nuclear Medicine, Inc. for the study of human T-lymphocyte trafficking and lymphocytic infiltration of tissues and organs.

Key Words: visilizumab; radiolabeling; biodistribution; molecular animal imaging

J Nucl Med 2009; 50:1683-1691

DOI: 10.2967/jnumed.108.059485

$\mathbf{F}$ or successful therapy with anti-CD3 monoclonal antibodies (mAbs), it is an important prerequisite that the target organ is indeed infiltrated by CD3-positive cells. Infiltration can be demonstrated by biopsy, although not always, particularly for intraabdominal organs. Furthermore, the biopsy reflects minimally the situation of the whole organ unless multiple random sites are tested. Therefore, we hypothesized that the use of a radiolabeled antibody directed against the CD3 antigen might help for the selective detection of resting and activated T-lymphocytes and thus serve as a diagnostic tool for imaging T-cell traffic and lymphocytic infiltration of tissues and organs affected in autoimmune diseases. Thus, the use of a radiolabeled antibody would provide a rationale for treatment with anti-CD3 and a tool for therapy follow-up.

Visilizumab is an $\mathrm{IgG}_{2}$ isotype humanized monoclonal antibody $(\mathrm{mAb})$ characterized by non-Fc $\gamma \mathrm{R}$-binding due to mutation in the upper $\mathrm{CH} 2$ region of $\mathrm{IgG}_{2}$ and selective binding to the CD3 antigen (1). The human $\mathrm{IgG}_{2}$ isotype of the mAb decreases its ability to activate human complement or to interact with type I or type III Fc receptors (2).

More than $95 \%$ of circulating human peripheral T-cells and activated T-cells in inflamed tissues express CD3 antigen. In fact, there is a general consensus that CD3-positive T-cells may play an important role in inflammatory disease conditions. Several low-mitogenic anti-CD3 monoclonal antibodies have been tested for treatment for type I insulindependent diabetes mellitus (3), renal transplant rejection (4), and psoriatic arthritis $(5,6)$. Moreover, a murine $\mathrm{IgG}_{2}$ anti-CD3 
mAb OKT3 (muromonab [Orthoclone]; Ortho BioTech) is Food and Drug Administration-approved for the treatment of transplant rejection. The potential therapeutic effect of visilizumab has also been examined in several immune systemrelated disorders including ulcerative colitis (7), Crohn's disease (8), renal allograft, and acute graft-versus-host disease $(9,10)$. However, besides activity in these diseases, a rapid and severe lymphopenia has been observed after visilizumab infusion in humans (at pharmacologic doses of $10 \mu \mathrm{g} / \mathrm{kg}$ or more). The reason for this transient lymphopenia (that starts as early as $30 \mathrm{~min}$ after infusion of antibody) is unknown (11), as it is unknown the organ where lymphocytes migrate from blood after visilizumab infusion.

The rationale of the present study was to radiolabel visilizumab with ${ }^{99 \mathrm{~m}} \mathrm{Tc}$ and to check in vitro and in vivo its specificity for CD3-positive cells for the study of human T-lymphocyte trafficking. We also aimed to clarify the fate of human T-lymphocytes after the administration of pharmacologic doses of visilizumab.

\section{MATERIALS AND METHODS}

\section{Antibodies}

Visilizumab was kindly provided by PDL BioPharma. For all experiments, as control $\mathrm{mAb}$, we used a humanized $\mathrm{IgG}_{2}$ antibody, non-FcR binding like visilizumab but also non-CD3 binding, also kindly provided by PDL BioPharma. We tried both direct and indirect radiolabeling methods to label visilizumab and control $\mathrm{mAb}$ with ${ }^{99 \mathrm{~m}} \mathrm{Tc}$, to obtain a high labeling efficiency (LE) and specific activity (SA) without any modification in biologic activity of the antibody.

\section{Labeling of Visilizumab and Control mAb with ${ }^{99 m}$ Tc by Indirect Method}

Antibodies were labeled by conjugation with the heterobifunctional linker succinimidyl-6-hydrazinonicotinate hydrochloride (SHNH), obtaining a hydrazinonicotinate-antibody conjugate. Antibodies were concentrated using Centricon Ultracel YM-50 (Millipore Corp.) to a concentration of $5 \mathrm{mg} / \mathrm{mL}$ and then modified by conjugation with SHNH (SoluLink) in dimethylformamide (Sigma-Aldrich Chemical). In brief, a different molar ratio of $\mathrm{SHNH}$ (100 $\mathrm{mM}$ in dimethylformamide) was added dropwise to a stirred solution of antibody $(20 \mathrm{mM}$ in $0.1 \mathrm{M}$ phosphate buffer) and $100 \mathrm{mM}$ phosphate and $150 \mathrm{mM} \mathrm{NaCl}$ buffer solution, $\mathrm{pH}$ 7.6-8.0. The mixture was purified by G-25 Sephadex PD10 column (GE Healthcare) using nitrogen-purged cold phosphate-buffered saline (PBS) $(\mathrm{pH} 7.4)$ as eluant. To couple the mAb-SHNH complex efficiently with ${ }^{99 \mathrm{~m}} \mathrm{Tc}$, reduce the percentage of colloid formation, and verify the influence of the amount of coligand on LE, titrations of tricine $(100 \mathrm{mg} / \mathrm{mL}$; Sigma-Aldrich Chemicals) and $\mathrm{SnCl}_{2}(2 \mathrm{mg} / \mathrm{mL}$ in $0.1 \mathrm{M} \mathrm{HCl}$; Sigma-Aldrich Chemicals) were performed with the mAb-SHNH complex $(100 \mu \mathrm{g})$ in $1 \mathrm{M}$ sodium acetate $(\mathrm{pH} 5.5)$ and $1,110 \mathrm{MBq}$ of freshly eluted ${ }^{99 m} \mathrm{TcO}_{4}^{-}(100 \mu \mathrm{L})$, maintaining a constant volume of reaction.

\section{Labeling of Visilizumab and Control mAb with ${ }^{99 m T c}$ by Direct Method}

Both antibodies were also tested for labeling with ${ }^{99 \mathrm{~m}} \mathrm{Tc}$ using the 2-mercapthoethanol (2-ME) method as described by Mather and Ellison (12). Briefly, disulfide bridges were reduced using different molar ratios of 2-ME-to-mAb (1,070:1, 2,145:1, and 4,290:1) to achieve the best activation of the antibodies and consequently the highest LE. The activated antibodies were then purified using G-25 Sephadex PD10 columns and nitrogen-purged cold phosphate buffer ( $\mathrm{pH}$ 7.4) as eluant. Methylene diphosphonic acid (MDP; Amersham) was used as a weak competitive ligand. The bone scan kit (containing $10 \mathrm{mg}$ of $\mathrm{MDP}, 0.17 \mathrm{mg}$ of $\mathrm{SnCl}_{2}$, and $2 \mathrm{mg}$ of ascorbic acid) was reconstituted with $1 \mathrm{~mL}$ of nitrogen-purged normal saline. Different amounts (from 1 to 7 $\mu \mathrm{L})$ of methylene-diphosphonate were tested with $140 \mu \mathrm{g}$ of activated antibodies and $370 \mathrm{MBq}$ of ${ }^{99} \mathrm{TcO}_{4}^{-}$freshly eluted from a ${ }^{99} \mathrm{Mo} /{ }^{99 m} \mathrm{Tc}$ generator to achieve the highest LE.

\section{Quality Controls}

Quality controls were performed using instant thin-layer chromatography-silica gel (ITLC-SG) strips (VWR International). The strips were analyzed by a radioscanner (Bioscan Inc.) to quantitate the percentage of activity incorporated. In $0.9 \% \mathrm{NaCl}$ solvent (with normal ITLC-SG strips), the following were retention factors ( $\mathrm{R} f \mathrm{~s})$ :

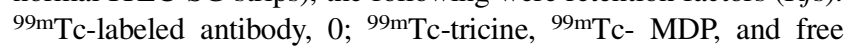
${ }^{99} \mathrm{mcO}_{4}^{-}, 0.9-1$. In $\mathrm{NH}_{3}: \mathrm{H}_{2} \mathrm{O}: \mathrm{EtOH}(1: 5: 2)$ solvent (with albuminabsorbed ITLC-SG strips), Rfs were ${ }^{99 \mathrm{~m}} \mathrm{Tc}$ colloids, 0 ; ${ }^{99 \mathrm{~m}} \mathrm{Tc}-$ labeled antibody, 1 ; and ${ }^{99 \mathrm{~m}} \mathrm{Tc}$ tricine and free ${ }^{99 \mathrm{~m}} \mathrm{TcO}_{4}{ }^{-}, 0.9-1$.

The stability of the labeled antibodies was measured in human serum at $37^{\circ} \mathrm{C}$ up to $24 \mathrm{~h}$. For this purpose, $100 \mu \mathrm{L}$ of ${ }^{99 m} \mathrm{Tc}-$ SHNH-visilizumab or ${ }^{99 m}$ Tc control mAb were added to $900 \mu \mathrm{L}$ of fresh human serum and incubated at $37^{\circ} \mathrm{C}$. The percentage of free ${ }^{99 \mathrm{~m}} \mathrm{Tc}$ or bound to antibody was measured at different time points $(1,3,6$, and $24 \mathrm{~h})$ by ITLC-SG.

A cysteine challenge assay was also performed to check the in vitro stability of the radiolabeled antibody. ${ }^{99 \mathrm{~m}} \mathrm{Tc}-\mathrm{SHNH}-$ visilizumab was incubated at different cysteine-to-mAb molar ratios, which ranged from 500:1 at the highest cysteine concentration to zero in the absence of cysteine, at $37^{\circ} \mathrm{C}$ for $1 \mathrm{~h}$. At the end of the incubation time, each reaction mixture was evaluated by ITLC$\mathrm{SG}$, although all known chemical forms of ${ }^{99 \mathrm{~m}} \mathrm{Tc}$-cysteine have an $R f$ of $0.5-1$ in normal saline.

Possible modifications induced by the conjugation procedure on the visilizumab were tested by sodium dodecyl sulphate polyacrylamide gel electrophoresis (SDS-PAGE) in nonreducing conditions, using Criterion Precast Gel (7.5\% Tris-HCl $1.0 \mathrm{~mm}$ ) (Bio Rad).

\section{In Vitro Competitive Binding Assay}

CD3 expression on human peripheral blood mononuclear cells (hPBMCs), HuT78, CEM, and Jurkat cell lines was tested by fluorescence-activated cell sorter analysis after staining cells with a fluorescein isothiocyanate-conjugated anti-CD3 antibody (Becton Dickinson) to verify which cell line presented the highest expression of CD3 receptors. Cells were maintained in a RPMI 1640 culture medium (Sigma-Aldrich Chemical) supplemented with $10 \%$ fetal calf serum, $2 \mathrm{mM}$ glutamine, $100 \mathrm{U}$ of penicillin per milliliter, $100 \mu \mathrm{g}$ of streptomycin per milliliter, $10 \mathrm{mM} 0.1$ $N$-(2-hydroxyethyl)piperazine- $N^{\prime}$-(2-ethanesulfonic acid) buffer ( $\mathrm{pH} 7.4$ ), and $2 \mathrm{mM}$ sodium pyruvate. Cells were cultured at 4-6 $\times 10^{5}$ cells $/ \mathrm{mL}$ at $37^{\circ} \mathrm{C}$ in a $\mathrm{CO}_{2}$ incubator for $1 \mathrm{wk}$.

A binding assay was performed on the human lymphoma cell line HuT78 to test the specificity of binding of labeled antibody to human CD3. Briefly, radiolabeled visilizumab was incubated, in triplicate, at different concentrations (from 10 to $0.010 \mathrm{nM}$ ) for 60 min at $4^{\circ} \mathrm{C}$ with $2 \times 10^{5} \mathrm{HuT78}$ cells. Specific binding was 
determined by performing the assay, in triplicate, in the presence and absence of a 100-fold molar excess of unlabeled visilizumab $(100 \mathrm{nM})$. At the end of the incubation time, cells were harvested by centrifugation $(5,000 \mathrm{~g}$ for $2 \mathrm{~min})$. The supernatant was collected in different vials, and then vials containing cells and supernatants were counted separately for radioactivity in a well $\gamma$-counter. The curve of specific binding was generated as the difference between total binding and nonspecific binding.

\section{Immunoreactive Fraction Assay (IRF)}

The IRF assay has been adapted with slight modifications from the method described by Lindmo et al. for determining the fraction of immunoreactive antibody by linear extrapolation to conditions representing infinite antigen excess (13).

The IRF assay was performed using a constant concentration of radiolabeled $\mathrm{mAb}$ and serial dilutions of hPBMCs. The hPBMCs were isolated from the blood of a single healthy donor, washed 3 times in PBS ( $\mathrm{pH} 7.4$ ), and diluted to a final concentration of $4 \times$ $10^{6}$ cells $/ \mathrm{mL}$ in a cold $1 \%$ bovine serum albumin (BSA)-PBS solution. All experiments were performed in duplicate. Radiolabeled $\mathrm{mAb}$, at a constant concentration of $50 \mathrm{ng} / \mathrm{mL}$ in a $1 \%$ BSA-PBS solution, was added to different amounts of cells (final concentration ranging from $2.6 \times 10^{6}$ to $0.08 \times 10^{6}$ cells $/ \mathrm{mL}$ ). Cells were incubated for $2 \mathrm{~h}$ at $4{ }^{\circ} \mathrm{C}$ and then washed twice with $500 \mu \mathrm{L}$ of a cold $1 \%$ BSA-PBS solution before cell-associated radioactivity in a single well $\gamma$-counter was counted.

\section{In Vivo Experiments by High-Resolution Imaging}

The high-resolution $\gamma$-camera (HRC) (Li-tech; S.r.l.) has been previously described $(14,15)$. The camera is composed of a crystal collimator coupled to an H8500 (Hamamatsu) position-sensitive photomultiplier tube, charge readout electronics, and data acquisition system. The system performs real-time acquisitions with a refresh time of $0.5 \mathrm{~s}$. The HRC energy resolution is about $20 \%$ at $140 \mathrm{keV}\left({ }^{99 \mathrm{~m} T c)}\right)$. The sensitivity is $210 \mathrm{cps} / \mathrm{MBq}$, and the uniformity is $\pm 5 \%$; the system provides 2.2 -mm intrinsic resolution suitable for our imaging experiments in vivo in small animals.

\section{In Vivo Targeting Experiment with HuT78 Cells}

To evaluate the ability of radiolabeled visilizumab to bind to HuT78 cells in vivo, we performed a targeting experiment in 9 athymic nude $\mathrm{BALB} / \mathrm{c} n u / n u$ mice. Mice were divided into 3 groups and subcutaneously implanted with an increasing number of HuT78 cells in the left thigh $\left(5 \times 10^{6}, 10 \times 10^{6}\right.$, or $20 \times 10^{6}$ cells, respectively). In the right thigh, mice were implanted with the same number of CD3-negative tumor cells (TPC1) as the control (16). After $2 \mathrm{~h}$, mice were injected in the tail vein with 11.1 MBq (approximately $1 \mu \mathrm{g}$ ) of radiolabeled visilizumab, and HRC images were acquired after 6 and $24 \mathrm{~h}$. Regions of interest were drawn over the left (target) and right (background) thighs, and target-to-background (T/B) ratios were calculated.

\section{In Vivo Competition Study of ${ }^{99 m}$ Tc-SHNH-Visilizumab}

Eight nude BALB/c nu/nu mice underwent a competition study to assess to what extent the uptake and retention of ${ }^{99 \mathrm{~m}} \mathrm{Tc}$-labeled anti-CD3 mAb to CD3-positive cells was displaced by an excess of unlabeled antibody. To this aim, mice were subcutaneously implanted with $20 \times 10^{6} \mathrm{hPBMCs}$ in Matrigel (BD Biosciences) in the right thigh. As a control, in the left thigh mice were implanted with the same volume of Matrigel, without cells. Four mice were preinjected intravenously with a 100-fold excess of unlabeled visilizumab immediately before the second injection of a tracer dose of $11.1 \mathrm{MBq}(\sim 1 \mu \mathrm{g})$ of ${ }^{99 \mathrm{~m}} \mathrm{Tc}$-visilizumab, in the tail vein; the remaining 4 mice received only $99 \mathrm{~m}$ Tc-visilizumab. HRC images were acquired after 6 and $24 \mathrm{~h}$. Regions of interest were drawn over the right (target) and left (background) thighs, and T/B ratios were calculated.

\section{Biodistribution of $99 \mathrm{~m}$ Tc-Labeled Visilizumab or 99mTc-Labeled Control mAb in Severe Combined Immunodeficient (SCID) Mice Reconstituted with hPBMCs}

The aim of these experiments was to check the biodistribution of ${ }^{99 m}$ Tc-labeled visilizumab or control $\mathrm{mAb}$ in SCID mice reconstituted with hPBMCs and treated with a pharmacologic dose of unlabeled visilizumab. Female SCID mice (10-12 wk old; Charles River Laboratories) were used. Mice were maintained in a specific pathogen-free facility without prophylactic antibiotics for 2-3 wk, and they received sterilized food and water ad libitum (17). One day before hPBMC administration, recipient SCID mice were depleted of natural killer cells and monocytes by whole-body irradiation with a $3-\mathrm{Gy}{ }^{137} \mathrm{Cs}$ source (18). All animal studies were performed in compliance with the local Ethical Committee and according to national regulations.

Immediately after reconstitution (intravenously, $8 \times 10^{6}$ hPBMCs per mouse), 3 mice were injected intravenously with $300 \mathrm{ng}(10 \mu \mathrm{g} / \mathrm{kg}$ dose $)$ of visilizumab, part of which was ${ }^{99 \mathrm{~m}} \mathrm{Tc}-$ labeled ( $\sim 30 \mathrm{ng}, 0.37 \mathrm{MBq})$. As a control, 3 mice were injected intravenously with $300 \mathrm{ng}(10 \mu \mathrm{g} / \mathrm{kg}$ dose $)$ of control mAb, part of which was ${ }^{99 \mathrm{~m}}$ Tc-labeled $(\sim 140 \mathrm{ng}, 0.37 \mathrm{MBq})$. Sequential images were acquired of all mice with the HRC at 1, 2, 3, 4, 5, $10,15,30,45,60,90,120$, and $180 \mathrm{~min}$ after visilizumab or control $\mathrm{mAb}$ injection. At the end of the imaging schedule, all mice were killed by neck dislocation, and major organs and tissues were removed (blood, lungs, liver, spleen, small bowel, large bowel, and kidneys), weighed, and counted for radioactivity in a single-well $\gamma$-counter. Organ radioactivity was represented as the percentage radioactivity per gram of tissue.

\section{Histology and Immunoperoxidase Staining of Mouse Organs}

To confirm the presence of hPBMCs in different tissues after visilizumab (or control $\mathrm{mAb}$ ) infusion, we histologically evaluated tissues from SCID mice at different time points. Specifically, organs were stored in formalin vials and paraffin-embedded. Fivemillimeter sections of major organs were freed of paraffin, and endogenous peroxidase activity was blocked with $\mathrm{H}_{2} \mathrm{O}_{2}$. A primary antibody against human CD3 (1:200 dilution; NeoMarkers) was incubated for $1 \mathrm{~h}$ at room temperature, followed by a secondary antibody incubation (biotinylated goat antimouse, 1:40 dilution) for $30 \mathrm{~min}$ at room temperature. Then, avidin biotin amplification (ABC kit; Dako) was added for $30 \mathrm{~min}$. Incubation with a 3-amino-9-ethylcarbazole chromogen kit (Sigma-Aldrich Chemical) at room temperature for 5-10 min produced a red reaction pigment. CD3-positive cells were counted separately at a magnification of $\times 400$ using a test grid with a $0.22 \mathrm{~mm}^{2}$ area.

\section{RESULTS}

Labeling of Visilizumab and Control mAb with ${ }^{99 m T c}$ by Indirect Method

The best molar ratio for conjugation of SHNH to $\mathrm{mAb}$ was $20: 1$. An amount of $10 \mu \mathrm{L}$ of tricine $(100 \mathrm{mg} / \mathrm{mL})$ and $10 \mu \mathrm{L}$ of $\mathrm{SnCl}_{2}(2 \mathrm{mg} / \mathrm{mL})$ was found to be the best for the 
highest LE with the lowest percentage of colloids to efficiently couple the visilizumab-SHNH conjugate (100 $\mu \mathrm{g})$ with ${ }^{99 \mathrm{~m}} \mathrm{Tc}$. A high LE ( $\geq 90 \%$ ) was achieved for the 99m Tc-SHNH-visilizumab complex with a high SA of $10,360-11,100 \mathrm{MBq} / \mathrm{mg}$ after $60 \mathrm{~min}$ of incubation using SHNH as a heterobifunctional linker. On the other hand, for the ${ }^{99 \mathrm{~m}} \mathrm{Tc}-\mathrm{SHNH}$-control mAb complex, a lower LE $(<40 \%)$ with low SA $(<4,440 \mathrm{MBq} / \mathrm{mg})$ was achieved. In SHNH determination using $o$-sulphonic benzaldehyde, an average of 4-10 hydrazino groups was found, conjugated to each molecule of visilizumab. Because of the low LE of the control $\mathrm{mAb}$, we did not use this labeling method; however, we selected this labeling method for visilizumab.

\section{Labeling of Visilizumab and Control mAb with ${ }^{99 m T c}$ by Direct Method}

For both antibodies, the highest LE was obtained using a molar ratio of 2,145:1 (2-ME:mAb). The control mAb showed the highest LE, with a negligible amount of colloids, on adding only $1 \mu \mathrm{L}$ of MDP (MDP kit). A low LE and SA were achieved using this radiolabeling method for visilizumab, whereas for the control $\mathrm{mAb}$ a high $\mathrm{LE}$ ( $\sim 99 \%)$ was achieved, thus avoiding G-25 Sephadex PD10 column purification. For the control $\mathrm{mAb}$, we used this labeling method for in vivo studies despite an SA $(\geq 2,600$ $\mathrm{MBq} / \mathrm{mg}$ ) that was lower than that obtained for visilizumab using the indirect labeling method.

\section{Quality Controls}

Both the ${ }^{99 \mathrm{~m} T c-S H N H-v i s i l i z u m a b}$ and the ${ }^{99 \mathrm{~m} T c}$ control $\mathrm{mAb}$ were stable when incubated in human serum at $37^{\circ} \mathrm{C}$ ( $87 \%$ for visilizumab and $89 \%$ for control $\mathrm{mAb}$ ) at 24 $\mathrm{h}$, as shown in Figure 1A. The cysteine challenge assay also demonstrated high stability up to a 500:1 ratio between cysteine and radiolabeled $\mathrm{mAb}$ (Fig. 1B).

SDS-PAGE of labeled, conjugated, and native visilizumab (Fig. 1C) showed no detectable modification of the molecule (in molecular weight), despite conjugation of 4-10 molecules of SHNH per molecule of antibody, as shown by a single band at $150 \mathrm{kDa}$. A minor band with high molecular weight ( $300 \mathrm{kDa}$ ) was found, possibly due to the presence of dimers of antibody in all lanes and in the autoradiographic lane, despite most radioactivity being associated with the $150-\mathrm{kDa}$ band of intact antibody.

\section{In Vitro Competitive Binding Assay}

When stained with fluorescein isothiocyanate-conjugated anti-CD3 antibody, hPBMCs showed a mean fluorescence intensity of 300 ( $80 \%$ positive cells), CEM of 38 (50\% positive cells), HuT78 of 18 ( $>95 \%$ positive cells), and Jurkat cells of 30 (60\% positive cells). We therefore used hPBMCs and HuT78 for different experiments. Specific saturation of receptors on HuT78 cells was obtained with concentrations of radiolabeled visilizumab above $5 \times$ $10^{-10} \mathrm{M}$ (Fig. 2). Radiolabeled antibody binding was displaced by a 100 -fold molar excess of unlabeled antibody,

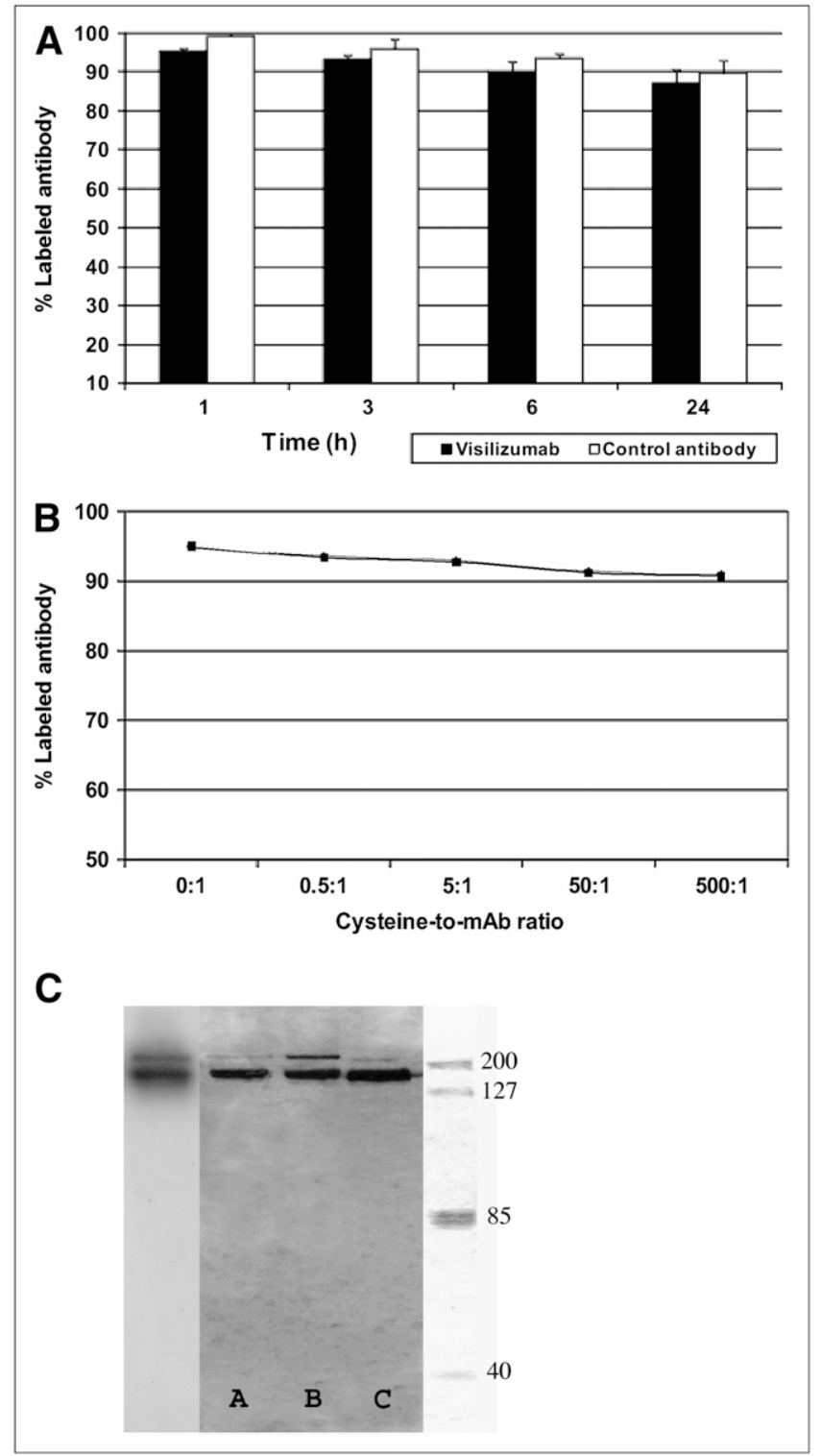

FIGURE 1. (A) Stability of $99 \mathrm{mTc}$ control $\mathrm{mAb}$ and $99 \mathrm{mTc}-$ $\mathrm{SHNH}$-visilizumab in plasma assessed by ITLC-SG at different time points. (B) Cysteine challenge assay demonstrating high stability of $99 \mathrm{mTC}-\mathrm{SHNH}$-visilizumab assessed by ITLC-SG at increasing ratio between cysteine and $\mathrm{mAb}$. (C) SDS-PAGE of $99 \mathrm{mTC}-\mathrm{SHNH}$-visilizumab performed in nonreducing condition showing conjugated (lane A), labeled (lane B), and native (lane $\mathrm{C}$ ) and associated radioactivity at level of conjugated antibody and at level of possible dimers of visilizumab (300 kDa).

and this showed that visilizumab retained its specific binding activity with CD3 receptors expressed on HuT78 cells, even after the radiolabeling with ${ }^{99 \mathrm{~m}} \mathrm{Tc}$.

\section{IRF Assay}

The immunoreactive fraction of radiolabeled visilizumab calculated in 2 experiments was $68 \%$ and $75 \%$, respectively. 


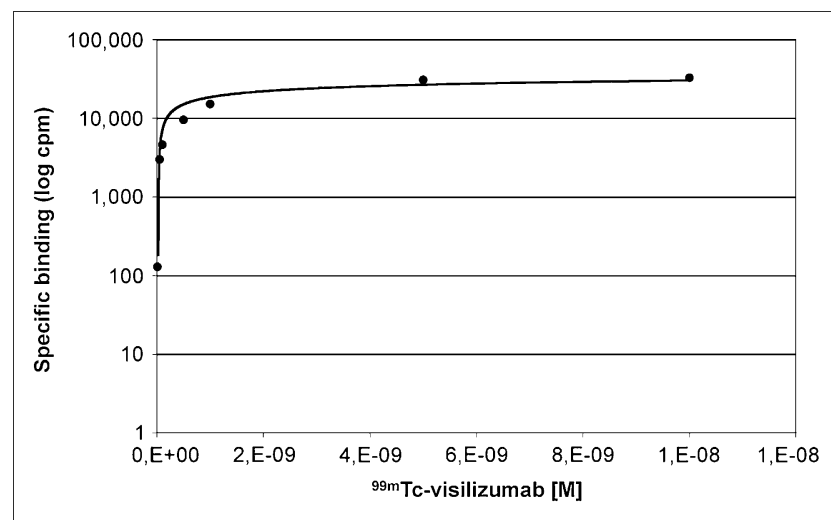

FIGURE 2. Results of binding assay of labeled visilizumab to HuT78 cells. $\mathrm{cpm}=$ counts $/ \mathrm{min}$.

\section{In Vivo Targeting Experiment with HuT78 Cells}

CD3-positive cells were detected by HRC imaging in mice implanted with $20 \times 10^{6} \mathrm{HuT78}$ cells (Fig. 3A). The quantification of ${ }^{99 \mathrm{~m} T c-S H N H-v i s i l i z u m a b ~ u p t a k e ~ s h o w e d ~}$ that the T/B ratio increased significantly with the number of cells both at 6 and at $24 \mathrm{~h}$ after injection $(0.98 \pm 0.03$ for $5 \times$ $10^{6}$ cells, $1.17 \pm 0.03$ for $10 \times 10^{6}$ cells, and $1.34 \pm 0.12$ for $20 \times 10^{6}$ cells at $6 \mathrm{~h}$; and $1.08 \pm 0.06$ for $5 \times 10^{6}$ cells, $1.30 \pm 0.17$ for $10 \times 10^{6}$ cells, and $1.56 \pm 0.13$ for $20 \times 10^{6}$ cells at $24 \mathrm{~h}$ ) (Fig. 3B). We also observed a small but statistically nonsignificant increase of uptake to cells from 6 to $24 \mathrm{~h}$ that may be explained by the fast binding kinetics of labeled mAb to target cells (within a few hours from injection), with no further significant increase with time.

\section{In Vivo Competition Study of ${ }^{99 m}$ Tc-SHNH-Visilizumab}

As shown in Figure 4, the uptake of radiolabeled antiCD3 mAb decreased after an excess of unlabeled anti-CD3 $\mathrm{mAb}$. Quantitative analysis of uptake showed a significant decrease ( $96 \%$ at $6 \mathrm{~h}$ and $87 \%$ at $24 \mathrm{~h}$ ) in T/B ratio in mice preinjected with cold visilizumab versus control mice (1.91 \pm 0.6 and $1.04 \pm 0.2$ at $6 \mathrm{~h} ; 3.06 \pm 0.8$ and $1.27 \pm 0.3$ at 24 h, control versus displaced animals, respectively, all $P<$ $0.05)$.

\section{Biodistribution of ${ }^{99 m}$ Tc-Labeled Visilizumab or 99mTc-Labeled Control mAb in SCID Mice \\ Reconstituted with hPBMCs}

Experiments performed on SCID mice reconstituted with hPBMCs and injected simultaneously with ${ }^{99 \mathrm{~m}} \mathrm{Tc}$-labeled visilizumab or ${ }^{99 \mathrm{~m}} \mathrm{Tc}$-labeled control $\mathrm{mAb}$ showed a different migration pattern of lymphocytes (as detected by histologic analysis) and different biodistribution of radioactivity as detected by scintigraphic imaging with an HRC.

In particular, ${ }^{99 \mathrm{~m}} \mathrm{Tc}-\mathrm{SHNH}-\mathrm{visilizumab}$, by binding to lymphocytes in blood, induced cells to accumulate in the liver, spleen, and small bowel of the SCID mice (Fig. 5). By contrast, ${ }^{99 \mathrm{~m} T c-l a b e l e d}$ control $\mathrm{mAb}$ showed a long resident time in the blood of mice (Fig. 6), with little accumulation of radioactivity and cells in the liver and
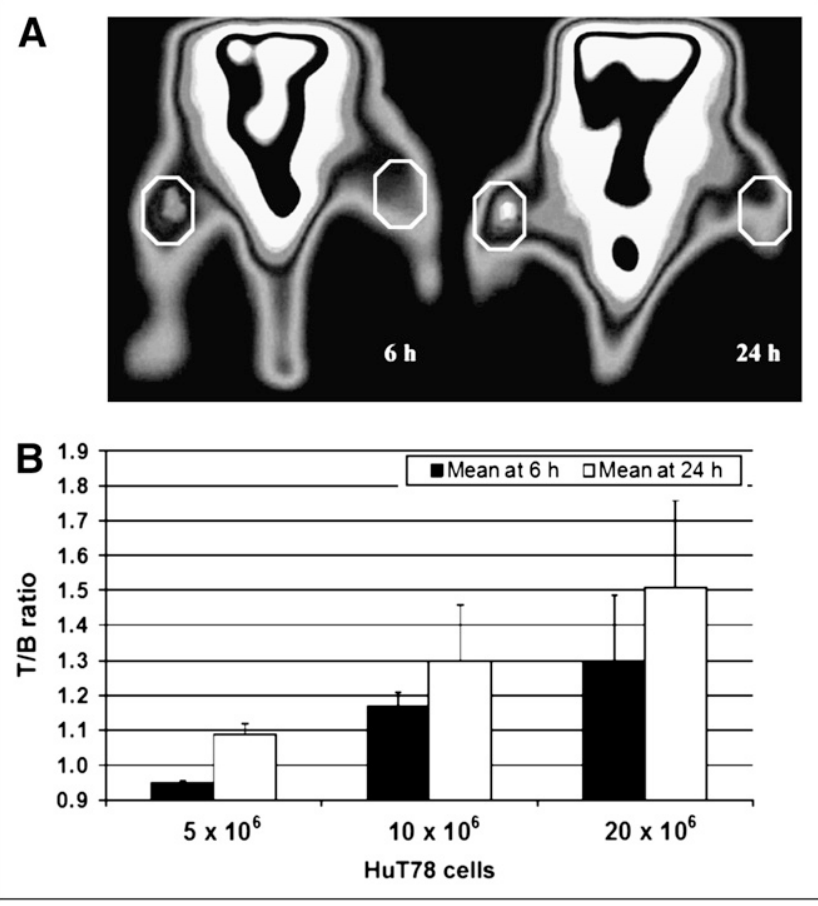

FIGURE 3. (A) Dorsal scintigraphic images obtained with $\mathrm{HRC}$, at 6 and $24 \mathrm{~h}$ in mice xenografted with $20 \times 10^{6} \mathrm{HuT7} 8$ tumor cells in left thigh and $20 \times 10^{6}$ TPC1 control cells in right thigh. Mice were injected with $11.1 \mathrm{MBq}$ of $99 \mathrm{mTc}-$ $\mathrm{SHNH}$-visilizumab. Higher uptake to HuT78 cells is visible as compared with CD3-negative cells. Regions of interests for T/B calculation are also shown. (B) Mean \pm SD of T/B ratios calculated for 3 groups of mice xenografted with $5 \times 10^{6}$, $10 \times 10^{6}$, and $20 \times 10^{6}$ cells, respectively.

small bowel. In particular, the calculation of radioactivity per gram of organ at $3 \mathrm{~h}$ showed a significant difference between visilizumab and control $\mathrm{mAb}$ in blood, with the radioactivity being higher in mice injected with control $\mathrm{mAb}(>60 \%)$. In the liver $(>400 \%)$, spleen $(>720 \%)$, and

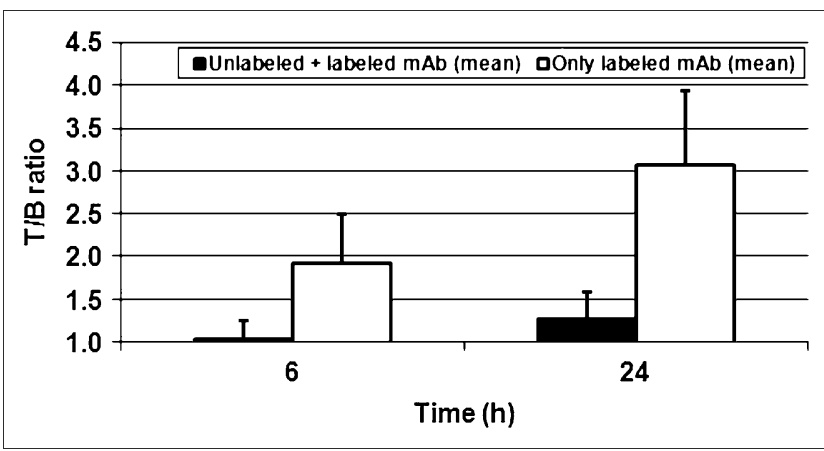

FIGURE 4. Mean $\pm S D$ of $T / B$ ratios calculated for 2 groups of mice xenografted with $20 \times 10^{6}$ hPBMCs and injected with either 100 -fold excess of unlabeled visilizumab immediately before tracer dose of $11.1 \mathrm{MBq}(\sim 1 \mu \mathrm{g})$ of $99 \mathrm{mTc}$-visilizumab or only tracer dose of ${ }^{99 \mathrm{mT}} \mathrm{Tc}$-visilizumab (as control mice). 


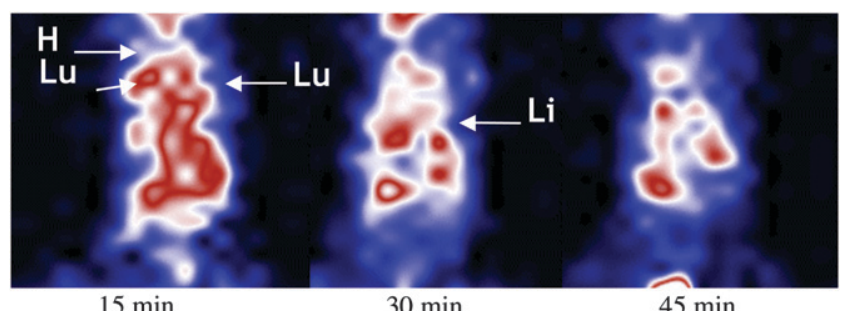

$15 \mathrm{~min}$

$30 \mathrm{~min}$

$45 \min$

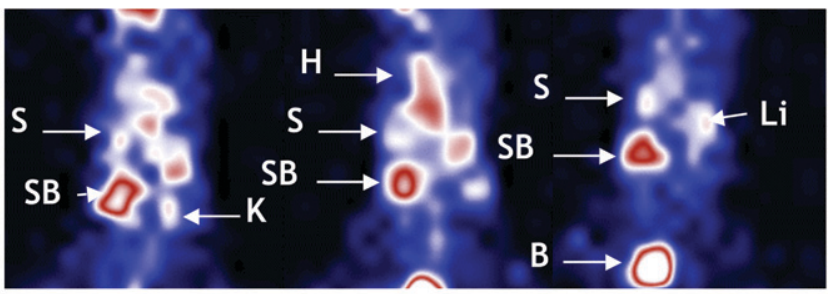

$60 \mathrm{~min}$

$90 \mathrm{~min}$

$180 \mathrm{~min}$

FIGURE 5. Scintigraphic images (dorsal view) of SCID mice injected simultaneously with $8 \times 10^{6}$ unlabeled hPBMCs and $300 \mathrm{ng}$ of visilizumab, part of which was $99 \mathrm{~m} T c-l a b e l e d(0.37 \mathrm{MBq}, 30 \mathrm{ng})$. Images were acquired after $15,30,45,60,120$, and $180 \mathrm{~min}$. Accumulation with time in spleen and small bowel is clearly detectable. $\mathrm{B}=$ bladder; $\mathrm{H}=$ heart; $\mathrm{LB}=$ large bowel; $\mathrm{Li}=$ liver; $\mathrm{Lu}=$ lungs; $\mathrm{S}=$ spleen; $\mathrm{SB}=$ small bowel.

small bowel $(>230 \%)$, radioactivity was higher in mice injected with visilizumab (Fig. 7). Minor and nonstatistically significant differences were found in the radioactivity counts in other organs including the lung, spleen, kidney, and large bowel, with the counts being higher for visilizumab than for control mAb (data not shown). Thus, it seems that after an intravenous injection of a pharmacologic dose of visilizumab, lymphocytes migrate from the blood to the liver, spleen, and small bowel. This finding was confirmed for the spleen and small bowel by histologic examination of tissues.

\section{Histology and Immunoperoxidase Staining of Mouse Organs}

Histologic examination of organs from mice injected either with visilizumab or with control mAb performed by immunoperoxidase staining with antihuman CD3 antibody showed statistically significant differences in the presence of human lymphocytes between visilizumab and control $\mathrm{mAb}-$ injected mice for the spleen and small bowel (Table 1) but not for the liver, lungs and large bowel. Interestingly, lymph nodes and intestinal mucosa-associated lymphoid tissue (MALT) showed the same behavior as the spleen in mice injected with visilizumab (data not shown). This finding further supports the hypothesis that visilizumab induces lymphocyte migration from blood into primary and secondary lymphoid organs together with the appendix.

\section{DISCUSSION}

Several attempts have been made in recent years to find specific and sensitive radiopharmaceuticals for imaging

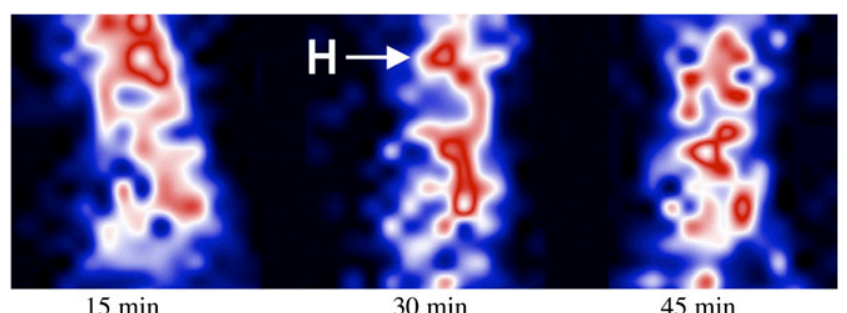

$15 \mathrm{~min}$

$30 \mathrm{~min}$

$45 \mathrm{~min}$

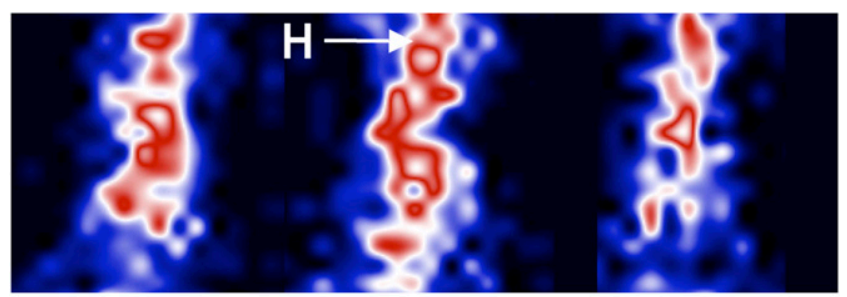

$60 \mathrm{~min}$

$90 \mathrm{~min}$

$180 \mathrm{~min}$

FIGURE 6. Scintigraphic images (dorsal view) of SCID mice injected simultaneously with $8 \times 10^{6}$ unlabeled hPBMCs and $300 \mathrm{ng}$ of control mAb, part of which was 99mTc-labeled $(0.37 \mathrm{MBq}, 140 \mathrm{ng})$. Images were acquired after $15,30,45,60,120$, and 180 min. Labeled antibody remains in blood for entire study time. $\mathrm{H}=$ heart.

chronic T-cell-mediated inflammation. Human polyclonal immunoglobulin is a non-antigen-specific $\mathrm{IgG}$ antibody that is labeled with ${ }^{99 m}$ Tc. Several studies demonstrated that the ${ }^{99 \mathrm{~m}} \mathrm{Tc}-$ human polyclonal immunoglobulin could be used not only for the assessment of disease activity but also as an effective prognostic tool for the inflammation-mediated disorders $(19,20)$. But data in the literature showed that IgG also accumulates in the inflammatory foci by nonspecific extravasation facilitated by locally enhanced vascular permeability (21). Therefore, there is a need for more specific and sensitive radiopharmaceuticals for the diagnosis of inflammation, possibly targeting different molecules such as lymphocyte activation markers, soluble cytokines, endothelial activation markers, or other cell receptors. The information provided by these radiopharmaceuticals could be useful also for therapy decision making and evaluating response to specific therapies. These radiopharmaceuticals may include radiolabeled anti-TNF $\alpha$, anti-CD25, antiCD20, anti-CD3, anti-CD4, and anti-E-selectin antibodies. Recently, 2 anti-TNF- $\alpha$ monoclonal antibodies (infliximab and adalimumab) have been labeled with ${ }^{99 \mathrm{~m}} \mathrm{Tc}$, and different scintigraphic studies in Crohn's disease (22) and rheumatoid arthritis (RA) patients (23-25) showed their potential use for therapy decision making and follow-up. A B-cell transmembrane antigen (CD20)-specific $\operatorname{IgG} 1 \kappa$ $\mathrm{mAb}$ (rituximab) was also recently radiolabeled with ${ }^{99 \mathrm{~m}} \mathrm{Tc}$ and found to be reliable in showing the disease activity in non-Hodgkin's lymphoma and RA patients $(26,27)$. Experience has also been cumulated for anti$\mathrm{CD} 25 \mathrm{mAb}$ radiolabeled with ${ }^{131} \mathrm{I},{ }^{99 \mathrm{~m}} \mathrm{Tc},{ }^{18} \mathrm{~F}$, and ${ }^{67} \mathrm{Ga}$ for imaging activated lymphocytes and monitoring response to anti-CD25 therapy $(27,28)$. A mAb against 


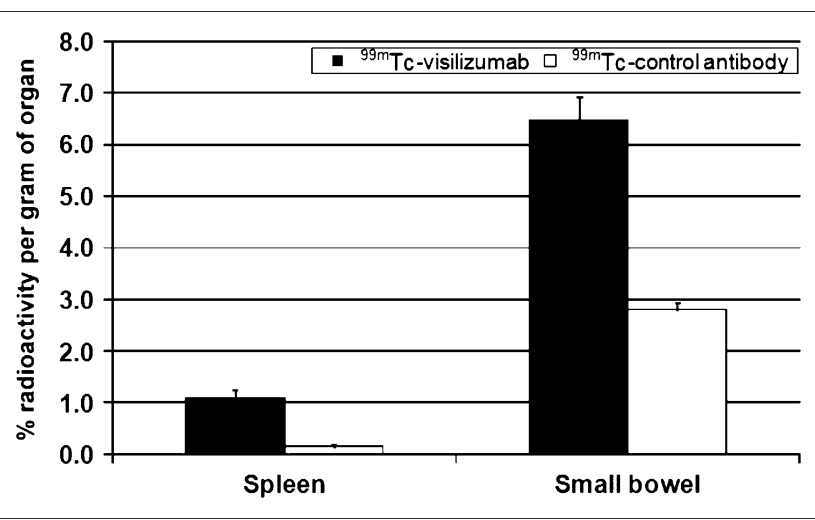

FIGURE 7. Radioactivity (\% of injected dose/g) in spleen and small bowel of SCID mice previously irradiated and reconstituted with hPBMCs and injected with $99 \mathrm{mTc}-\mathrm{SHNH}-$ visilizumab or ${ }^{99 \mathrm{~m} T c}$ control mAb. Animals (mean of $3 \pm \mathrm{SD}$ ) were killed $3 \mathrm{~h}$ after intravenous injection of labeled $\mathrm{mAb}$.

E-selectin, an endothelium-specific cytokine-inducible adhesion molecule, was radiolabeled and successfully studied in patients with active RA. This radiolabeled $\mathrm{mAb}$ was found to be more reliable than other commercially available radiopharmaceuticals (29). In several scintigraphic studies, 99mTc-labeled CD4-specific antibody proved to image inflamed joints in RA patients, and this has been proposed to assess the disease activity $(30,31)$. Moreover, an anti$\mathrm{CD} 3$ murine $\operatorname{IgG} 2 \alpha \mathrm{mAb}$, OKT3 (muromonab), was also labeled with ${ }^{99 \mathrm{~m}} \mathrm{Tc}$, and in different studies authors concluded that ${ }^{99 \mathrm{~m}} \mathrm{Tc}-\mathrm{OKT} 3$ imaging could be useful as a measurement of therapeutic effectiveness in acute renal transplant rejection and in RA (32,33). Unfortunately, OKT3 is of murine origin and showed side effects after administration in humans (34). Visilizumab, by contrast, is a humanized anti-CD3 monoclonal antibody, and if radiolabeled, visilizumab may provide a valuable diagnostic tool for imaging T-cell traffic and lymphocytic infiltration in tissues and organs affected by different autoimmune diseases. We therefore tried to label visilizumab with ${ }^{99 \mathrm{~m}} \mathrm{Tc}$. We tried both direct and indirect labeling procedures to develop a reliable and simple method that allows the formation of a stable ${ }^{99 \mathrm{~m}} \mathrm{Tc}$ conjugate with no modification in its biologic activity. The labeling procedure described here is easy and rapid, and using tricine as a coligand we were able to stabilize the coordination of ${ }^{99 \mathrm{~m}} \mathrm{Tc}$ to the SHNH-visilizumab conjugate and achieve a high LE ( $\geq 90 \%)$ and a high SA $(10,360-11,100 \mathrm{MBq} / \mathrm{mg}$ ) without the need of postlabeling purification. By contrast, the control $\mathrm{mAb}$ used in our experiments was labeled with a direct method using 2-ME reduction because we achieved a high LE of approximately $99 \%$ without the presence of colloids and therefore had no need of postlabeling purification. Both radiolabeled antibodies were stable in normal saline and serum up to $24 \mathrm{~h}$.

Results of the targeting experiment in mice showed an in vivo accumulation of radiolabeled visilizumab to HUT78 cells with time, proportional to the number of implanted cells. In vivo competition (unlabeled vs. labeled $\mathrm{mAb}$ ) was performed in mice using hPBMCs instead of HuT78 cells and proved in vivo the specificity of ${ }^{99 \mathrm{~m}} \mathrm{Tc}$-visilizumab binding to $\mathrm{CD} 3$. We also found a higher $\mathrm{T} / \mathrm{B}$ ratio when using hPBMCs instead of the same number of HuT78 cells, and this is in line with the higher CD3 expression on cell surface of hPBMCs than HuT78.

Finally, using radiolabeled antibody and a model of SCID mice reconstituted with hPBMCs, we were able to demonstrate the effect of pharmacologic doses of visilizumab on resting circulating peripheral blood CD3-positive cells. Images acquired and single organ counting, supported by the histologic data, confirmed that visilizumab induces lymphocyte migration mainly into the small bowel and spleen. We also examined a few little lymph nodes and MALT tissue and found the same behavior as for the spleen, indicating that lymphocytes migrate from blood into primary and secondary lymphoid organs including the appendix. Therefore, the high liver uptake of visilizumab, compared with the control mAb, is not due to lymphocyte migration into this organ because not many lymphocytes were found at histologic examination and this phenomenon should be attributed to different antibody kinetics.

From the clinical point of view, our results show that ${ }^{99 \mathrm{~m}} \mathrm{Tc}-$ SHNH-visilizumab can be used for diagnostic purposes, presumably without any side effects because of its high SA. Indeed, only $30 \mu \mathrm{g}$ of radiolabeled visilizumab could

\section{TABLE 1. Number of Lymphocytes per Histologic Field in Different Tissues}

$\begin{array}{lccc}\text { Mouse organ } & \begin{array}{c}\text { No. of lymphocytes* } \\ \text { (in visilizumab-injected mice) }\end{array} & \begin{array}{c}\text { No. of lymphocytes* } \\ \text { (in control mAb-injected mice) }\end{array} & t \text { test }(P) \\ \text { Lung } & 2.7 \pm 1.72 & 2.85 \pm 1.35 & 0.38 \\ \text { Liver } & 0.5 \pm 0.61 & 0.8 \pm 0.62 & 0.06 \\ \text { Large bowel } & 0.15 \pm 0.49 & 0.15 \pm 0.37 & 0.50 \\ \text { Kidney } & 0 \pm 0.0 & 0 \pm 0.0 & \mathrm{NA} \\ \text { Spleen } & 5.5 \pm 2.35 & 3 \pm 1.59 & 0.0002 \\ \text { Small bowel } & 18.15 \pm 3.27 & & 0.003 \\ & & & \\ \text { *Values given by mean of reading } 20 \text { different fields; } \times 400 \text { magnification. } & & \\ \text { NA }=\text { not applicable. } & & \end{array}$


be sufficient for a diagnostic scan in humans (i.e., with $370 \mathrm{MBq}$ ) as compared with approximately $700-1,000 \mu \mathrm{g}$ $(10-15 \mu \mathrm{g} / \mathrm{kg})$ given for therapy. This radiopharmaceutical could also be useful for therapy decision making in patients who are candidates for anti-CD3 therapy by providing a rationale for such a therapy by showing CD3-positive lymphocytes infiltrating target organs.

In addition, we provided the explanation of a pathophysiologic finding observed in patients after the pharmacologic administration of visilizumab (i.e., the lymphopenia associated with migration of lymphocytes from blood to peripheral lymphoid organs). This explanation seems to rule out the hypothesis of lymphocyte migration to nonlymphoid organs, such as the liver and lungs, in which they are not used to home and in which they could induce tissue damage by activation and cytokine release.

In the future, we plan to use ${ }^{99 \mathrm{~m}} \mathrm{Tc}-\mathrm{SHNH}-$ visilizumab for imaging lymphocytic infiltration in patients affected by autoimmune diseases and for therapy decision making and therapy follow-up in patients treated with anti-CD3 mAb. Finally, because visilizumab has a short plasma half-life it could also be radiolabeled with positron emitters (such as ${ }^{68} \mathrm{Ga}$ or ${ }^{18} \mathrm{~F}$ ) that may provide a short-life radiopharmaceutical for specific targeting and sensitive detection of T-lymphocytes with PET cameras.

\section{CONCLUSION}

Visilizumab can be efficiently labeled with ${ }^{99 \mathrm{~m}} \mathrm{Tc}$ with high LE and can be used for imaging T-cell traffic and lymphocytic infiltration in tissues and organs. The defined method is simple, rapid, reliable, and effective, yielding a high SA without the loss of immune reactivity and with excellent cell targeting in vivo. In particular, we were able to demonstrate that ${ }^{99 \mathrm{~m}} \mathrm{Tc}-\mathrm{SHNH}$-visilizumab targets CD3positive cells in different mouse models, and a pharmacologic dose of unlabeled visilizumab induces migration of hPBMCs from circulation into small bowel and peripheral lymphoid organs (spleen, lymph nodes, and MALT tissue in small bowel). This migration can be visualized with ${ }^{99 \mathrm{~m} T c-}$ SHNH-visilizumab imaging.

\section{REFERENCES}

1. Trajkovic V. Nuvion: Protein design labs. Curr Opin Investig Drugs. 2002; 3:411-414.

2. Carpenter PA, Appelbaum FR, Corey L, et al. A humanised non-FcR-binding anti-CD3 antibody, visilizumab, for treatment of steroid-refractory acute graftversus-host disease. Blood. 2002;99:2712-2719.

3. Ishikawa H, Ochi H, Chen ML, Frenkel D, Maron R, Weiner HL. Inhibition of autoimmune diabetes by oral administration of anti-CD3 monoclonal antibody. Diabetes. 2007;56:2103-2109.

4. Friend PJ, Hale G, Chatenoud L, et al. Phase I study of an engineered aglycosylated humanized CD3 antibody in renal transplant rejection. Transplantation. 1999;68:1632-1637.

5. Utset TO, Auger JA, Peace D, et al. Modified anti-CD3 therapy in psoriatic arthritis: a phase I/II clinical trial. J Rheumatol. 2002;29:1907-1913.

6. Alegre ML, Peterson LJ, Xu D, et al. A non-activating "humanized" anti-CD3 monoclonal antibody retains immunosuppressive properties in vivo. Transplantation. 1994;57:1537-1543.
7. Yu QT, Saruta M, Papadakis KA. Visilizumab induces apoptosis of mucosal T lymphocytes in ulcerative colitis through activation of caspase 3 and 8 dependent pathways. Clin Immunol. 2008;127:322-329.

8. Hommes D, Targan S, Dignass A, et al. A phase I study: visilizumab therapy in Crohn's disease refractory to infliximab treatment [abstract]. Gastroenterology. 2006;130:A-111.

9. Carpenter PA, Lowder J, Johnston L, et al. A phase II multicenter study of visilizumab, humanized anti-CD3 antibody, to treat steroid-refractory acute graft-versus-host disease. Biol Blood Marrow Transplant. 2005;11:465-471.

10. Norman DJ, Vincenti F, de Mattos AM, et al. Phase I trial of HuM291, a humanised anti-CD3 antibody, in patients receiving renal allograft from living donors. Transplantation. 2000;70:1707-1712.

11. Plevy S, Salzberg B, Van Assche G, et al. A phase I study of visilizumab, a humanized anti-CD3 monoclonal antibody, in severe steroid-refractory ulcerative colitis. Gastroenterology. 2007;133:1414-1422.

12. Mather SJ, Ellison D. Reduction-mediated technetium- $99 \mathrm{~m}$ labeling of monoclonal antibodies. J Nucl Med. 1990;31:692-697.

13. Lindmo T, Boven E, Cuttitta F, et al. Determination of the immunoreactive fraction of radiolabeled monoclonal antibodies by linear extrapolation to binding at infinite antigen excess. J Immunol Methods. 1984;72:77-89.

14. Soluri A, Scopinaro F, De Vincentis G, et al. ${ }^{99 M}$ TC [13LEU] bombesin and a new gamma camera, the imaging probe, are able to guide mammotome breast biopsy. Anticancer Res. 2003;23:2139-2142.

15. Scopinaro F, Massari R, Varvarigou AD, et al. High resolution small-animal single photon emission computed tomography: uptake of [ $\left.{ }^{99 \mathrm{~m}} \mathrm{Tc}\right]$ bombesin and [ ${ }^{123}$ I] ioflupane by rat brain. Q J Nucl Med Mol Imaging. 2007;51:204210 .

16. Ishizaka Y, Itoh F, Tahira T, et al. Presence of aberrant transcripts of ret protooncogene in a human papillary thyroid carcinoma cell line. Jpn J Cancer Res. 1989;80:1149-1152.

17. Kawata A, Yoshida M, Okazaki M, et al. Establishment of new SCID and nude mouse models of human B leukemia/lymphoma and effective therapy of the tumors with immunotoxin and monoclonal antibody: marked difference between the SCID and nude mouse models in the anti-tumor efficacy of monoclonal antibody. Cancer Res. 1994;54:2688-2694.

18. Shpitz B, Chambers CA, Singhal AB, et al. High level functional engraftment of severe combined immunodeficient mice with human peripheral blood lymphocytes following pre-treatment with radiation and anti-asialo GM1. J Immunol Methods. 1994;169:1-15.

19. Cindas A, Gokce-Kutsal Y, Kirth PO, Caner B. Scintigraphic evaluation of synovial inflammation in rheumatoid arthritis with ${ }^{99 \mathrm{~m}}$ technetium-labeled human polyclonal immunoglobulin G. Rheumatol Int. 2001;20:71-77.

20. Ortapamuk H, Hosal B, Naldoken S. The role of Tc-99m polyclonal human immunoglobulin G scintigraphy in Graves' ophthalmopathy. Ann Nucl Med. 2002;16:461-465.

21. Malviya G, de Vries EFJ, Dierckx RA, Signore A. Radiopharmaceuticals for imaging chronic lymphocytic inflammation. Braz Arch Bio Tech. 2008;50: $1-13$.

22. D'Alessandria C, Malviya G, Viscido A, et al. Use of a ${ }^{99 \mathrm{~m}} \mathrm{Tc}$ labeled anti-TNF $\alpha$ monoclonal antibody in Crohn's disease: in vitro and in vivo studies. $Q \mathrm{~J} \mathrm{Nucl}$ Med Mol Imaging. 2007;51:334-342.

23. Chianelli M, D'Alessandria C, Conti F, et al. New radiopharmaceuticals for imaging rheumatoid arthritis. Q J Nucl Med Mol Imaging. 2006;50:217225.

24. Barrera P, Oyen WJG, Boerman OC, van Riel PLCM. Scintigraphic detection of tumour necrosis factor in patients with rheumatoid arthritis. Ann Rheum Dis. 2003;62:825-828.

25. Malviya G, D'Alessandria C, Lanzolla T, et al. 99m-technetium labeled antiTNF $\alpha$ antibodies for the therapy decision making and follow-up of patients with rheumatoid arthritis [abstract]. $Q \quad \mathrm{~J}$ Nucl Med Mol Imaging. 2008;52(suppl 1):13.

26. Stopar TG, Mlinaric-Rascan I, Fettich J, Hojker S, Mather SJ. ${ }^{99 m}$ Tc-rituximab radiolabeled by photo-activation: a new non-Hodgkin's lymphoma imaging agent. Eur J Nucl Med. 2006;33:53-59.

27. Malviya G, Lagàna B, Signore A, Dierckx RA. Radiolabeled peptides and monoclonal antibodies for therapy decision making in inflammatory diseases. Curr Pharm Des. 2008;14:2401-2414.

28. Kim IS, Yoo TM, Kobayashi H, et al. Chemical modification to reduce renal uptake of disulfide-bonded variable region fragment of anti-Tac monoclonal antibody labeled with ${ }^{99 \mathrm{~m}}$ Tc. Bioconjug Chem. 1999;10:447-453.

29. Jamar F, Chapman PT, Manicourt D-H, Glass DM, Haskard DO, Peters AM. A comparison between ${ }^{111} \mathrm{In}$-anti-E-selectin $\mathrm{mAb}$ and ${ }^{99} \mathrm{Tc}^{\mathrm{m}}$-labeled human nonspecific immunoglobulin in radionuclide imaging of rheumatoid arthritis. $\mathrm{Br} \mathrm{J}$ Radiol. 1997;70:473-481. 
30. Becker W, Emmrich F, Horneff G, et al. Imaging rheumatoid arthritis specifically with technetium 99m CD4-specific (T-helper lymphocytes) antibodies. Eur J Nucl Med. 1990;17:156-159.

31. Kinne RW, Becker W, Schwab J, et al. Comparison of 99Tcm-labeled specific murine anti-CD4 monoclonal antibodies and nonspecific human immunoglobulin for imaging inflamed joints in rheumatoid arthritis. Nucl Med Commun. 1993;14:667-675.
32. Martins FPP, Souza SAL, Gonçalves RT, Fonseca LMB, Gutfilen B. Preliminary results of $\left[{ }^{99 \mathrm{~m}} \mathrm{Tc}\right] \mathrm{OKT} 3$ scintigraphy to evaluate acute rejection in renal transplants. Transplant Proc. 2004;36:2664-2667.

33. Marcus C, Thakur ML, Huynh TV, et al. Imaging rheumatic joint diseases with anti-T lymphocyte antibody OKT-3. Nucl Med Commun. 1994;15:824-830.

34. Sgro C. Side-effects of a monoclonal antibody, muromomab CD3/Orthoclone OKT3: bibliographic review. Toxicology. 1995;105:23-29. 